\title{
Comparative bioelectrochemical study of core-shell nanocluster films with ordinary layer-by-layer films containing heme proteins and $\mathrm{CaCO}_{3}$ nanoparticles
}

\author{
Hongyun Liu, Naifei Hu* \\ Department of Chemistry, Beijing Normal University, Beijing 100875, China
}

*Corresponding author. Fax: +86-10-5880-2075. Email: hunaifei@ bnu.edu.cn.

Table S1. Adsorption amounts of proteins in each bilayer in [protein-m] nanoclusters. Results were estimated based on UV-vis spectra of the Soret band of heme proteins at $408 \mathrm{~nm}$ and the average of 5 replicate experiments

\begin{tabular}{|c|c|c|c|c|}
\hline \multirow[b]{2}{*}{$\mathrm{m}$} & \multicolumn{2}{|c|}{$\begin{array}{l}\text { Ratio of adsorbed protein to } \mathrm{CaCO}_{3} \\
\left(\mathrm{mg} \text { protein } / \mathrm{mg} \mathrm{CaCO}_{3}\right)\end{array}$} & \multicolumn{2}{|c|}{$\begin{array}{l}\text { Number of protein molecules adsorbed } \\
\text { on each } \mathrm{CaCO}_{3} \text { in each bilayer }\end{array}$} \\
\hline & $\mathrm{Mb}$ & $\mathrm{Hb}$ & $\mathrm{Mb}$ & $\mathrm{Hb}$ \\
\hline 1 & $0.058 \pm 0.01$ & $0.121 \pm 0.02$ & $328 \pm 56$ & $181 \pm 30$ \\
\hline 2 & $0.084 \pm 0.02$ & $0.132 \pm 0.03$ & $476 \pm 113$ & $198 \pm 45$ \\
\hline 3 & $0.096 \pm 0.03$ & - & $544 \pm 170$ & - \\
\hline
\end{tabular}


Table S2. QCM results for $\left\{[\text { protein-m]/PSS }\}_{n}\right.$ and $\left\{\text { protein } / \mathrm{CaCO}_{3}\right\}_{\mathrm{n}}$ films on Au/MPS and $\mathrm{Au} / \mathrm{MPS} / \mathrm{PDDA} / \mathrm{CaCO}_{3}$ surface, respectively. $1 \mathrm{~Hz}$ of frequency decrease corresponds to $1.35 \mathrm{ng}$ of mass increase. The geometric area of QCM gold electrodes is $0.196 \mathrm{~cm}^{2}$. The density is assumed to be $1.3 \mathrm{~g} \mathrm{~cm}^{-3}$ for protein, $2.55 \mathrm{~g} \mathrm{~cm}^{-3}$ for $\mathrm{CaCO}_{3}$ nanoparticles and for [protein-m] nanoclusters.

\begin{tabular}{llllll}
\hline & \multicolumn{2}{l}{$\begin{array}{l}\text { Negative charged layer } \\
\text { Films }\end{array}$} & $\begin{array}{l}\text { Positive charged layer } \\
\text { (nanocluster or protein) }\end{array}$ & \\
\cline { 2 - 6 } & $\Delta \mathrm{F} / \mathrm{Hz}$ & $\mathrm{d} / \mathrm{nm}$ & $\Delta \mathrm{F} / \mathrm{Hz}$ & $(\Delta \mathrm{M} / \mathrm{A}) /\left(\mu \mathrm{g} \mathrm{cm}^{-2}\right)$ & $\mathrm{d} / \mathrm{nm}$ \\
\hline$\{[\mathrm{Mb}-1] / \mathrm{PSS}\}_{\mathrm{n}}$ & $+323 \pm 116$ & - & $-801 \pm 169$ & 5.52 & 10.8 \\
$\{[\mathrm{Mb}-2] / \mathrm{PSS}\}_{\mathrm{n}}$ & $+349 \pm 149$ & - & $-1201 \pm 234$ & 8.27 & 16.2 \\
$\{[\mathrm{Mb}-3] / \mathrm{PSS}\}_{\mathrm{n}}$ & $+412 \pm 178$ & - & $-1652 \pm 354$ & 11.4 & 22.2 \\
$\{[\mathrm{Hb}-1] / \mathrm{PSS}\}_{\mathrm{n}}$ & $+303 \pm 98$ & - & $-1968 \pm 600$ & 13.6 & 26.5 \\
$\{[\mathrm{Hb}-2] / \mathrm{PSS}\}_{\mathrm{n}}$ & $+342 \pm 114$ & - & $-2438 \pm 830$ & 16.8 & 32.9 \\
$\{\mathrm{Mb} / \mathrm{CaCO} 3\}_{\mathrm{n}}$ & $-245 \pm 40$ & 3.3 & $-116 \pm 38$ & 0.80 & 3.0 \\
$\{\mathrm{Hb} / \mathrm{CaCO} 3\}_{\mathrm{n}}$ & $-262 \pm 33$ & 3.5 & $-146 \pm 21$ & 1.00 & 3.8 \\
\hline
\end{tabular}




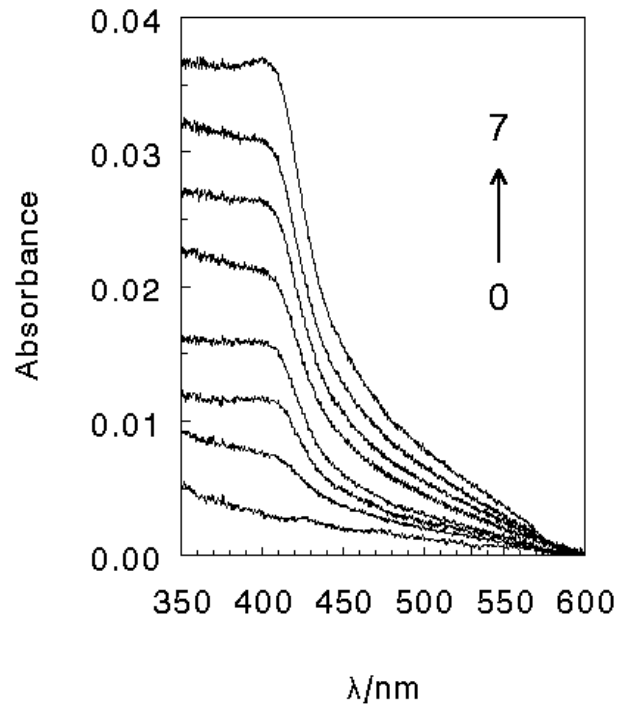

Figure S1. UV-vis absorption spectra of $\{[\mathrm{Mb}-2] / \mathrm{PSS}\}_{\mathrm{n}}$ films grown with the number of bilayers (n) on quartz slide surface.
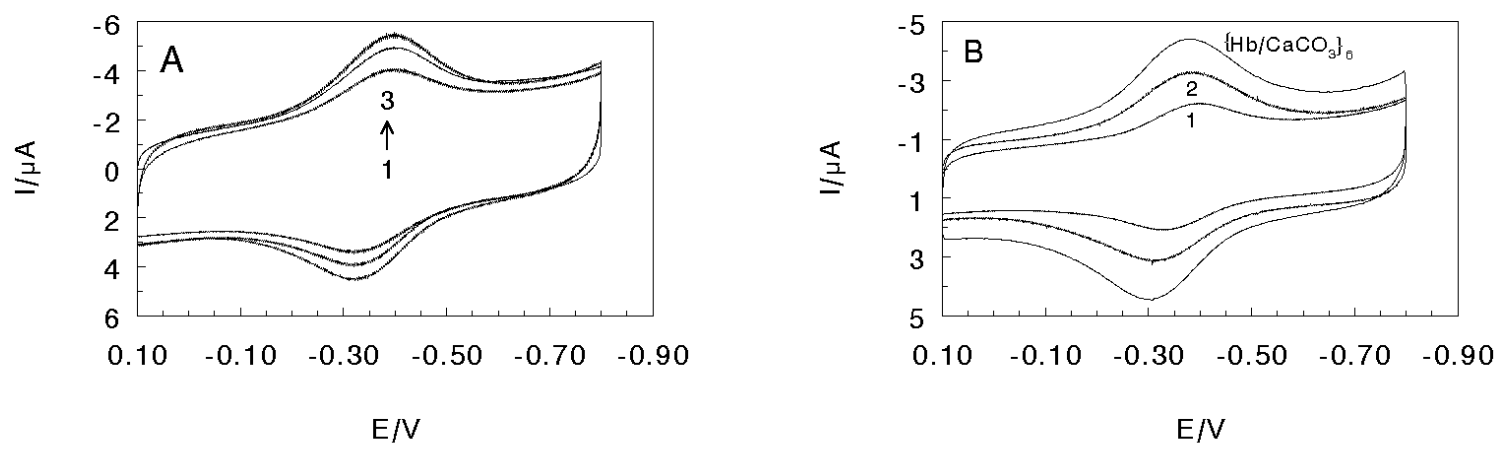

Figure S2. CVs in $\mathrm{pH} 7.0$ buffers at $0.2 \mathrm{~V} \mathrm{~s}^{-1}$ for $(\mathrm{A})\{[\mathrm{Mb}-\mathrm{m}] / \mathrm{PSS}\}_{7}$ films with different $\mathrm{m}$, and (B) $\{[\mathrm{Hb}-\mathrm{m}] / \mathrm{PSS}\}_{6}$ films with different $\mathrm{m}$ and $\left\{\mathrm{Hb} / \mathrm{CaCO}_{3}\right\}_{6}$ films on $\mathrm{PG} / \mathrm{PDDA} / \mathrm{CaCO}_{3}$ surface. 


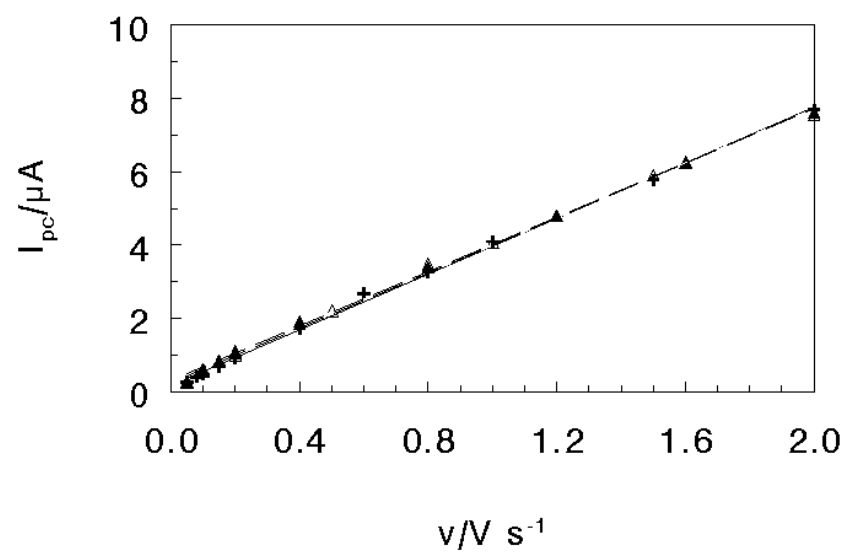

Figure S3. Dependence of reduction peak current on scan rate for $\{[\mathrm{Hb}-2] / \mathrm{PSS}\}_{6}$ films in $\mathrm{pH} 7.0$ buffers with rotating rate of $0(\Delta), 200(\Delta)$, and $2000 \mathrm{rpm}(+)$.

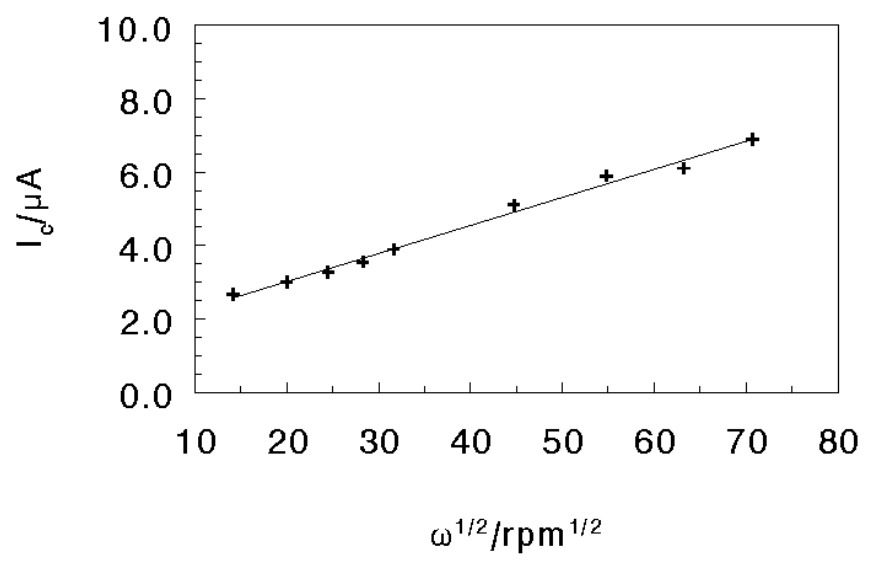

Figure S4. Levich plot of RDV steady state current vs square root of rotating rate $\left(\omega^{1 / 2}\right)$ at scan rate of $0.1 \mathrm{~V} \mathrm{~s}^{-1}$ for $\{[\mathrm{Hb}-1] / \mathrm{PSS}\}_{6}$ films in the presence of $25 \mu \mathrm{M} \mathrm{H}_{2} \mathrm{O}_{2}$. 

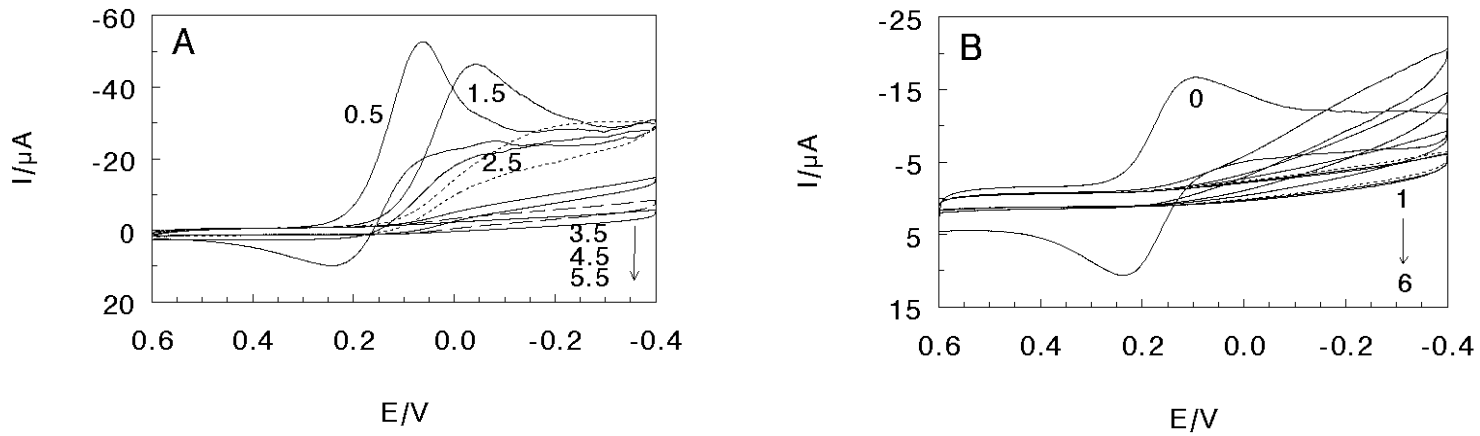

Figure S5. CVs of $0.5 \mathrm{mM} \mathrm{K}_{3} \mathrm{Fe}(\mathrm{CN})_{6}$ in solutions containing $0.05 \mathrm{M} \mathrm{KCl}$ at $0.2 \mathrm{~V} \mathrm{~s}^{-1}$ at $\{[\mathrm{Hb}-$ 2]/PSS $\}_{\mathrm{n}}$ film electrodes with (A) [Hb-2] as the outermost layer and (B) PSS as the outermost layer. The number in the figures reflects the number of [Hb-2]/PSS bilayers (n). 


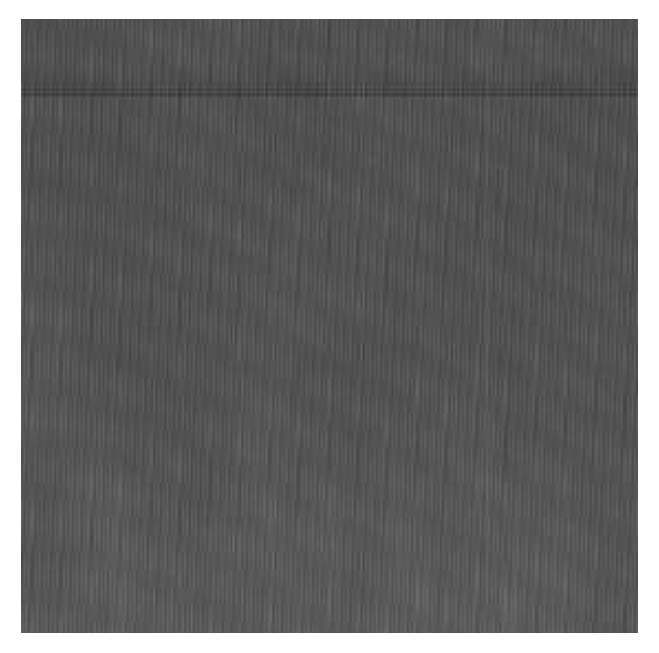

a

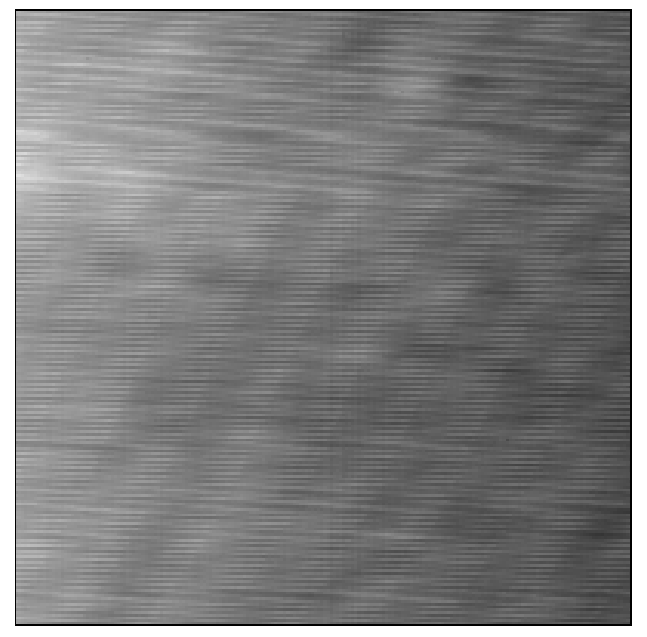

c

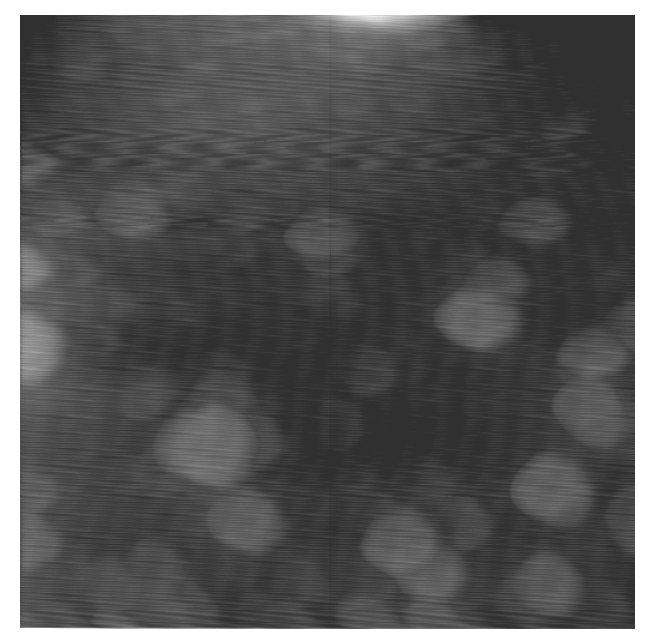

b

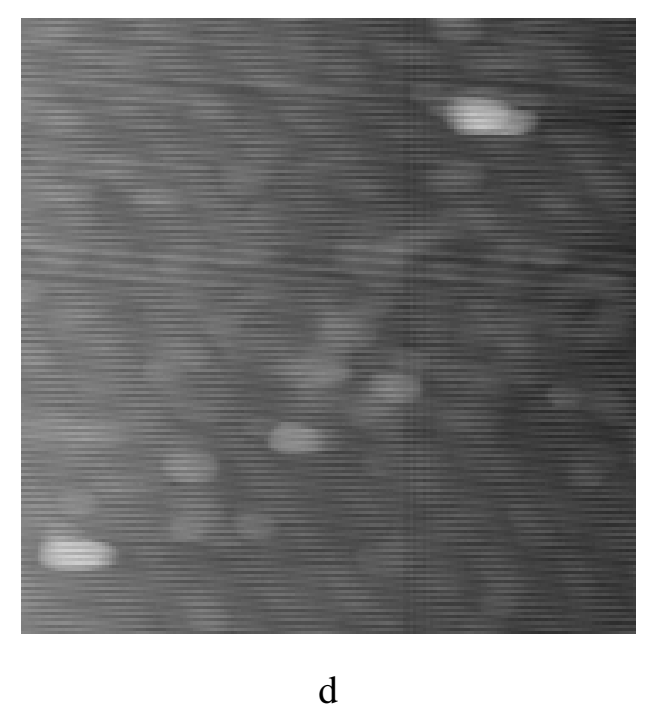

Figure S6. Top views of AFM images of (a) bare silicon wafer, (b) $\{[\mathrm{Mb}-3] / \mathrm{PSS}\}_{1}$ films, (c) PDDA films, and (d) $\mathrm{PDDA} / \mathrm{CaCO}_{3} / \mathrm{Mb}$ films. The $\mathrm{X}$-axis scale of the pictures is $1 \mu \mathrm{m}$. 